\title{
الموانئ البحرية في محافظة جنوب سيناء \\ ودورها فى التنمية
}

إعداد

أ. د د عادل محمد شاويش

الجغرافيا الاقتصادية

كلية الآداب - جامعة المنوفية 


\section{الموانئ البحرية في محافظة جنوب سيناء

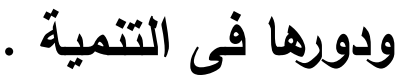

- تمهيد:

يساهم النقل البحرى بدور كبير لحساب عملية التنمية سواء على المستوى الاقليمى أو المستوى القومى ، وتتمثل تلك المساهمة فى توفير وسيلة نقل تنخفض بها تكلفة النقل بدرجة كبيرة مقارنة بوسائل النقل بالسيارات أو القطارات ناهيك عن النقل الجوى ، ويرجع إنخفاض تكلقة النقل البحرى إلى عدة عوامل منها ، كبر حجم الحمولة المنقولة والتى قـ تصل مئات الأطنان ، يضاف الى ذلك انذفاض تكلفة الطريق الذى تتحرك عليه المركبات حيث يتمثل الطريق فى الخليج أو البحر أو المحيط حيث أن معظم هذه الطرق الملاحية هى من نتاج الجغرافية الطبيعية ، وذلك باستثاء التجهيزات المرتبطة بصناعة الموانئ البحرية التى تبدأ منها الرحلة البحرية أو تنتهى إليها. لقد شهـ النقل البحري في الريع قرن الأخير تظورا كبيرا على المستوى العالمي ، وذلك استجابة لمعدلات النمو المرتفعة في حركة التجارة الدولية، وذلك ليس جليدا حيث أن ظهور شبكات النقل بأنواعها المختلفة وتطورها على مر التاريخ لم يكن سوى استجابة لنمو وتظور حركة التبادل التجاري بين البشر سواء على المستوى المحلي أو الإقليمي أو العالمي (صلاح الثامي -

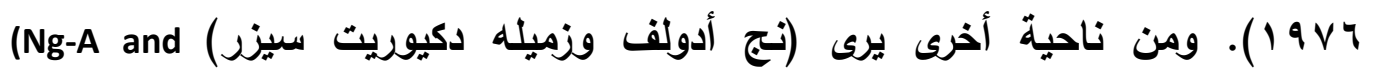
Ducruet,C-2014)

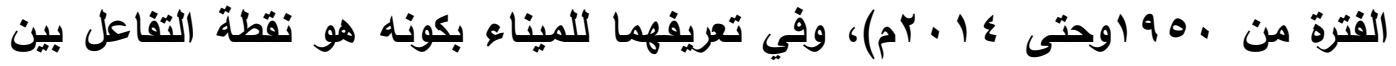
اليابس والبحر، حيث تعتبر الموانئ بليهيا بمثابة مراكز اقتصادية وحضارية للمدن وإقليمها المحيط بها، ومع التطور التكنولوجي في صناعة السفن والتطور الهائل في مجال التجارة الدولية، والذي انعكس على طبيعة الموانئ وطرق تثنغلها، مما انعكس على نوعية المدارس العلمية التي تناولت دراسة الموانئ البحرية حيث تعتبر من الموانئ من 
مثلها مثل باقي فروع جغرافية النقل من الدراسات المتعددة الأنظمة حيث يتناولها المتخصصون في علوم النقل البحري والاقتصاديين والجغرافيين. ويلا شك أن نفوذ خدمة الموانئ البحرية فى الكثير من دول العالم لايقتصر على خدمة ظهيرها المباشر ، بل يمتد نفوذها الى أكثر من إقليم داخل الدولة وقد يمتد الظهير للاولة كلها ، ويذلك لايقتصر

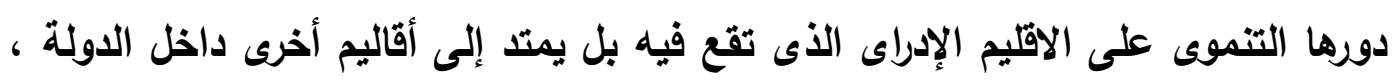

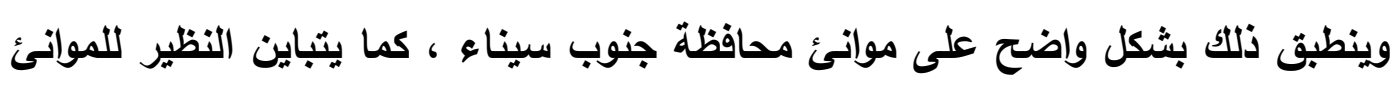

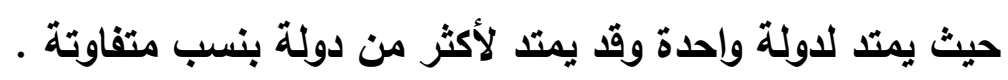
- مناهج وأساليب البحث : لقد اسـتذم البحث عدة منـاهج وأسـاليب لتحقيق الأهداف المرسـومة للبحث ، ومسن المناهج التي استخدمها البحث: المنهج التحليليAnalyses approach وكذلك منهج التفاعل المكانيSpatial approach، بهدف تحليل حركة النقل عبر مواني البحر الأحمر وخليج

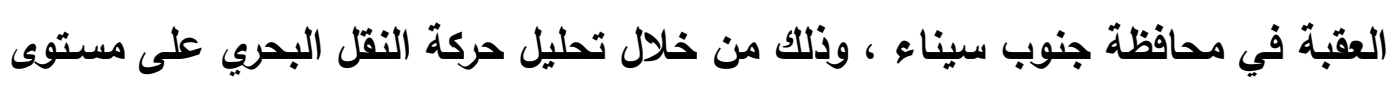
السلع والبضائع، وكذلك نقل الركاب، سواء العمالة المهاجرة أو حركة السياحة الأجنبية

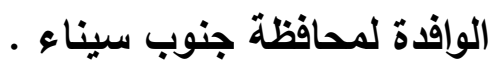

$$
\text { - دراسات سابقة : - }
$$

توجد عدد من الدراسات المتخصصة في جغرافية الموانئ والتي ظهرت خلال العقود الخمس الأخيرة ومنها ما يتعلق بأنظمة الموانئ البحرية وإلتنمية المكانية وعلاقتها بشبكة فيكة فئه

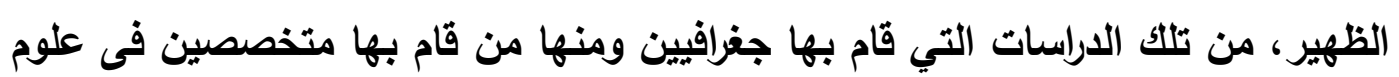
النقل البحري ، ومنهم متخصصين فى اقتصاديات النقل البحري ، ومنهم متخصصين في إدارة النقل البحري، ويمسح سريع خلال المواقع الاكترونية للاراسات التي تناولت الموانئ والنقل البحري خلال العقود الأخيرة نجد دكيوريت وزملائه (Ducruct,C et al-2009)الذين

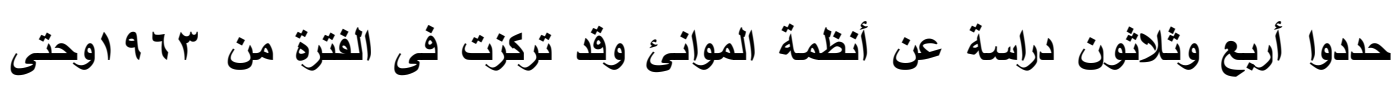




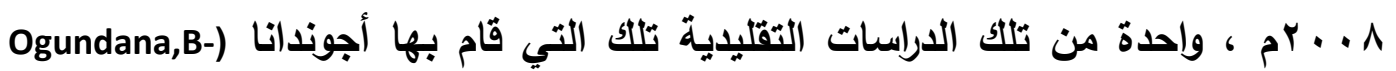
1970عن تطور الموانئ في نيجيريا وقبلها دراسة تافي وزملائه عن تطور النقل في الاول النامية ، تحليل مقارن (Taaffe,E,et al-1963) ، وقد تتاولت تلك الدراسات العلاقة بين تطور شبكة المواني البحرية وكل من شبكة الطرق التي تربطها بظهيرها الاقتصادي. وأيضا نموذج هيوث (Hayuth,Y-1981 عن الحاويات ومفهوم مراكز النقل، وكذلك دراسة باركي (Barke,M-1986)، عن التقل والتجارة ودور المواني البحرية ، والتي ركزت على ظهور موانئ صغيرة على خط الساحل لكي تثكل عنصرا ناهضا فى منظومة الموانئ التي تثشكل من موانئ كبيرة محورية تقع بينها موانسئ صغيرة . - الخصائص الاقتصادية للظهيز المباشر للموانئ فى جنوب سيناء : يؤثر البناء الاقتصادى لأى إقليم فى صناعة الظهير المباشر للموانئ البحرية وخاصة فيما يتعلق بالأنشطة الزراعية أو التعدينية أو السياحية والتى تنعكس على حركة الصادرات التى تمثل فائض النشاط الاقتصادى فى الاقليم أو حركة الواردات التى تتمثل فيما تحتاحه الهياكل الاقتصادية أو الاجتماعية فى الاقليم، هذا إضافة، إلى حركة الصادرات والواردات فى الأقاليم المجاورة فى الدولة، وحتى الاول الدول الأخرى أحيانا التى تمثن نظيرا للميناء ، مثل دور ميناء العقبة فى حركة الورادات والصادرات العراقية خلال العقود الثثلاث الأخيرة ، وتتباين هياكل البنية الاقتصادية فى المحافظة من حيث تأثيرها على حركة الموانئ فى المحافظة ، ويتضح ذلك من خلال النظر لمؤشرات تلكك الهياكل فيمايلى :

ومن خلال النظر لمؤثرات هيكل الاقتصاد الزراعي فى المحافظة فتبلغ المساحة الكلية

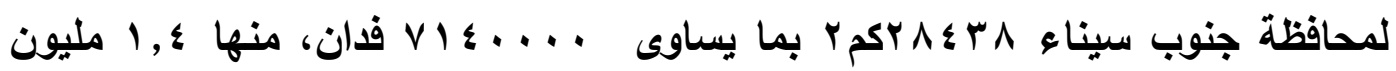
فدان تصلح للزراعة تقع على خليج السويس ، ومايقرب من بـ ألف فدان على ساحل خليج العقبة ، في حين لايزرع منها فعليا سوى هب ا ا افدان ، تبلغ المساحة المنزرعة 


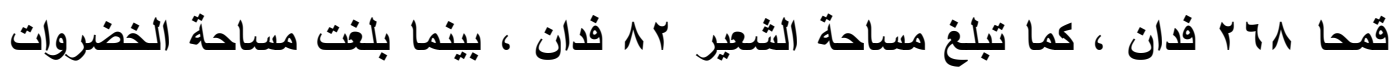

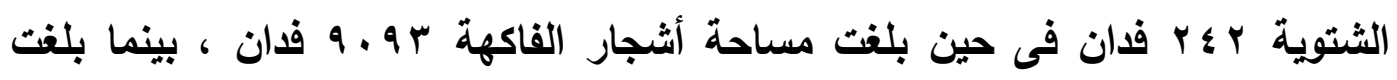

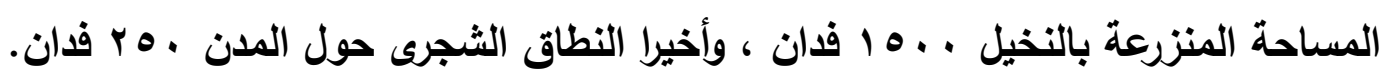
وتتواجد مناطق الزراعة الرئيسة فى محافظة جنوب سيناء فى مركز سدر وخاصة شرق الطريق الساحلى شمال مدينة رأس سدر وحتى الحدود مع محافظة السويس على مسافة ؛ سكم ، حيث توجد جيوب زراعية صغيرة حيثما تتواجد مصادر المياه الجوفية ويقوم بمعظمها السكان البدو ، ومنها وادى فيران التابع لمركز أبو رديس ووادى الطور شمال مدينة الطور ، وتتكون الزراعة فى جنوب سيناء من قطاعين فرعيين : الأول وهو الزراعة ولهات التقليدية القائمة على الرعى المتنقل أو شبه المتنقل ، بالاضافة الى زراعة مناطق محدودة تروى بمياه الأمطار والنوع الثانى وهو الزراعة غير التقليدية أو إنتاج المحاصيل باستخدام نظم الري الحديثة ، ومن ناحية أحرى تتساقط الأمطار على مرتفعات جنوب شبه الهيه جزيرة سيناء وتجرى فى أوديه أغلبها من النوع الخانقى العميق الذى تمتاز جوانبه بثدة انحدارها ، ويتماثسى خط تقسيم المياه مع القمم الجبلية المرتفعة ومنه تندر الأودية نحو الشرق ، كما تنحدر أودية أخرى ناحية خليج السويس غربا من أهمها : وادى سدر ووادى غرندل ووادى وسيط ووادى فيران وغيرها ، وتتميز هذه الأودية بإتساع مجاريها الدنيا كونها تجرى فى أرض سهلية منبسطة كما أن غناها النسبى بالحياه النباتية واضح ، ويحد خط المطر المتساوى هبمم كل الاقليم الساحلى شرقا وغريا ، ويذا تدخل محافظة

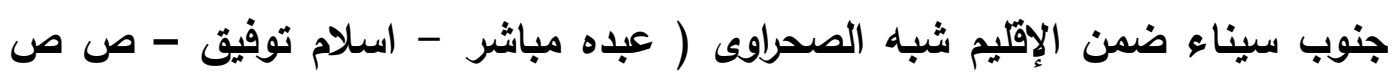

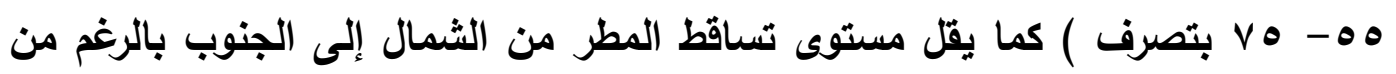
أنه يزداد فى الهضاب ومناطق الجبال حيث يقدر تقرير ديمس ومور متوسط الأمطار السنوية بحوالى ب rمم فى منطقة الهضاب كما يبلغ ب آمم فى مناطق الجبال الجنويبة ويرجع ارتفاع كمية المطر للتأثيرات الجبلية ، وتسقط الأمطار غالبا بين أكتوير ومايو ، كما تسقط أحيانا بغزارة فى شكل سيول كبيرة ( محافظة جنوب سيناء - دليل توصيف 
البيئة والتنمية - ص ص \& «- بتصرف ) ويالطبع ينعكس ذلك على الاقتصاد الززاعى فى محافظة جنوب سيناء . وتساهم عملية صيد الأسماك بدور محدودر فى إقتصاد المحافظة رغم أنها تطل على ظليجين بمسافة ـ 11 كم وتتركز مناطق الصيد فى كل موانئ رأس سدر والطور ودهب حيث تساهم فى توفير فرص عمل لما يقري من . 10.

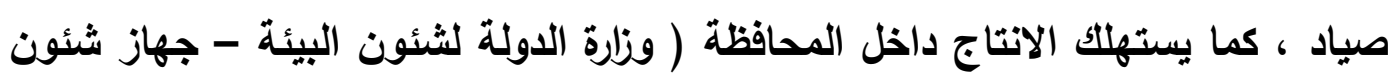

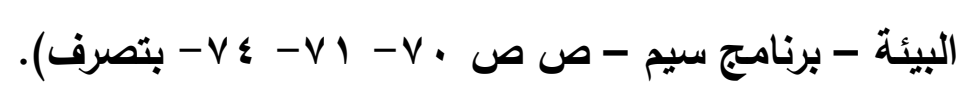

ومما سبق نجد ضعف مساهمة قطاع الزراعة فى البناء الاقتصادى لمحافظة جنوب سيناء ، وذلك عكس معظم محافظات الجمهورية ،مما يقلل فرص الطلب على تصدير الحاصلات الزراعية والسمكيه عبر موانئ المحافظة فى المستقبل المنظور ولكى تثكل ظهيرا زراعيا

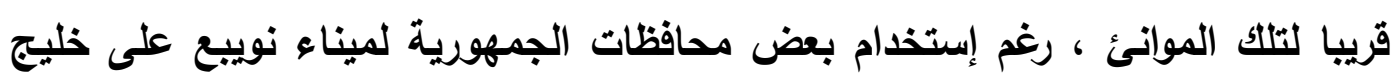
العقبة لتصدير بعض الحاصلات الزراعية وخاصة الفواكه والخضر لاول الخليج العربية

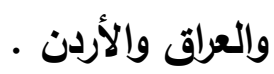

أما بالنسبة لاور قطاع البترول فى عملية البناء الاقتصادي للمحافظة فيتمثل فى

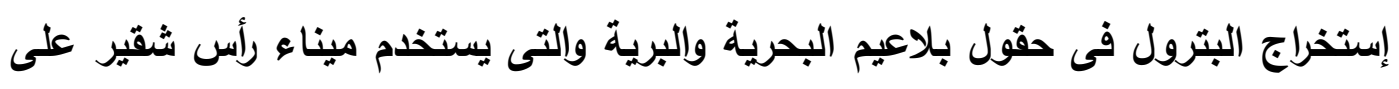

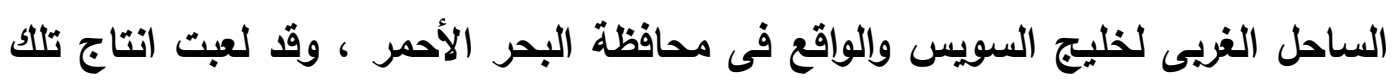

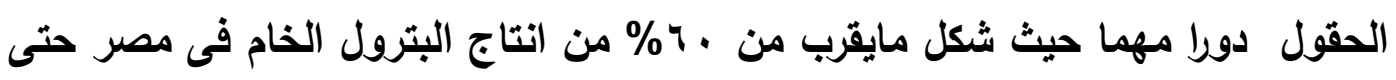

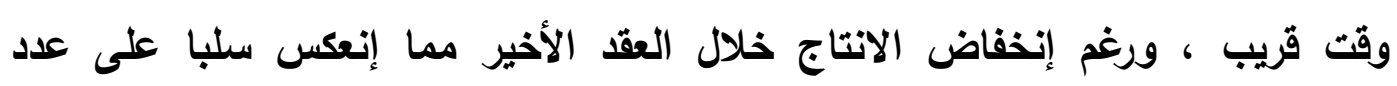
العاملين من سكان جنوب سيناء حيث لايزيدون عن .... عامل سواء في الاستخرج أو فى معمل التكرير الذى يقع فى وادى فيران ـ وفيما يتطلق بالتعلين والمحاجر فيتم

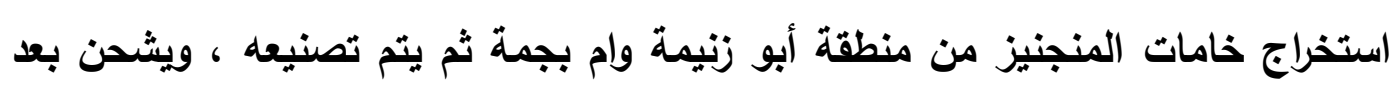

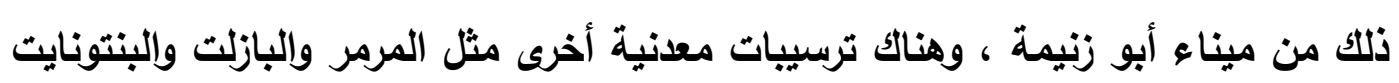
والطفلة واللالومايت والطفلة والجبس والكاولين والرمل الأبيض ، كما توجد كميات كبيرة من الجرانيت والرخام والرمال والحصى فى العديد من العواقع بمحافظة جنوب سيناء ، وذلك التكان 
يغنى أن قطاع الثروة المعدنية فى محافظة جنوب سيناء ذو توجه برى داخلى حتى الآن باستثناء المنجنيز الذي يتجه للخارج عبر ميناء أبو زنيمة في محافظة جنوب سيناء .

وأخيرا يأتي النشاط السياحي والذي يعتبر عماد الاقتصاد فى المحافظة والذي يؤثثر ويثأثر بطبيعة الموانئ والمرافئ فى المحافظة كما سنرى فى حركة الركاب السائحين فى ميناء شرم الثيخ الأي يعتبر من الموانئ المتخصصة فى المجال السياحى وكنلك بعض المرافئ التى تساهم فى نشاط الغوص وسياحة الأعماق ، وطبقا لمؤشرات نهاية العقد الأخير فقا. بلغ عدد المنشآت السياحية فى جنوب سيناء أكثر من 1 ـ 1 منشأة سياحية وأكثر من

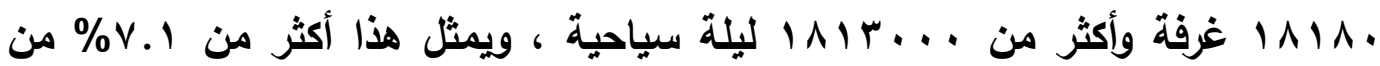
إجمالى المنشآت السياحية فى مصر ، وأكثر من 10. 1\% من إجمالى الغرف وأكثر من

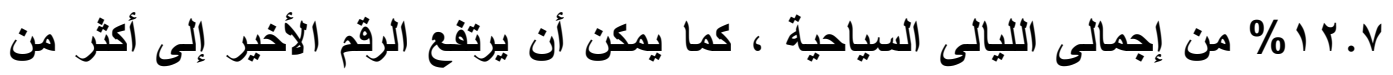
ذلك إذا حسب عدد السياح الأجاتب فقط ، كما يبلغ إجمالى الايرادات مايقرب من خمس إجمالى إيرادات السياحة فى مصر · ل

ومن ناحية أخرى تعتمد العملية السياحية فى جنوب سيناء على سياحة المنتجعات البحرية بثكل رئيسي ، كما بلغت نسبة السياح الأجانب مايقرب من أريعة أخماس السائحين القادمين للمحافظة (†^\%\%) مقابل ؛ ؟1\% للسائحين المصرين ذلك خلال العقد الأول من القرن الحادي والعشرون ، وتعتبر منطقة شرم الثيخ المقصد الرئيس للحركة السياحية فى المحافظة يليها كل من دهب ونويبع ورأس سدر ، وقد استمر هدف السياح الاجاتب بالدرجة الأولى وكذلك العرب والمصريين من القدوم للمحافظة كمقصد سياحي منذ

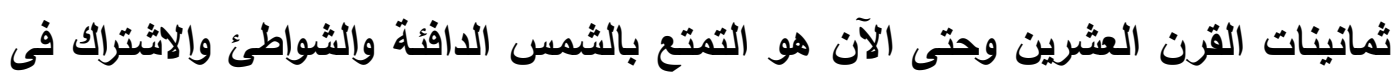
الأنشطة البحرية ومنها رياضة الغوص التى تتمتع بثهرة عالمية ، هذا إضافة الى لى مانى مشاركة السياحة الثقافية وسياحة السفارى والمغامرات الطبيعية بالرغم أن أعداد المشتركين فى هذه الأنثطة ليست كبيرة . 


\section{- الموانئ والمرافئ فى محافظة جنوب سيناء :}

يعرف المرفأ في جغرافية النقل البحري بأنه هو القطاع من سطح البحر الذي يكون محميا بطريقة طبيعية أو صناعية ، ويتضمن هذا القطاع المحجوز مساحة من الماء الهادئ العميق الذي يسبغ قدرا من الحماية للسفن عندما يجهز أو يعد لاستقبالها ، وليس من الضرورى أن يستخدم الانسان كل مرفأ ، كما يجب أن يكون المرفأ المناسب لكى تتهيا الفرصة لقيام وتجهيز الميناء ، وقد يصتع الانسان هذا المرفأ لكى يصنع الميناء ، بمعنى أن كل ميناء وهى مصنوعة تتضمن مرفأ بالضرورة ، ويستوى فى ذلك أن يكون المرفأ طبيعيا أو اصطناعيا ، ولايمكن أن تكون الميناء من غير مرفأ مناسب،ولكن يمكن أن

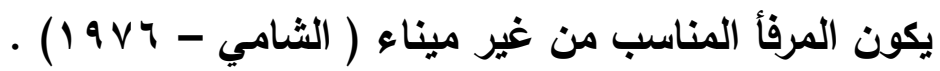

والموانئ فى معظمها تعتبر وليدة العمل الاصطناعى ، ومن شأن هذا العمل أن يجهز الموقع فى الظهير المباشر الذي يطل على المرفأ بكل التجهيزات التى تخلم الملاحة البحرية وعملية النقل البحرى.وتتمثل هذه التجهيزات فى أعمال إنثائية صناعية كالأرصفة والمرابط فى المرفأ ، وكذلك المستودعات والورش وأبنية التشغيل ومراقبة الحركة فى ظهير المرفأ، وأيضا الأوناش وخطوط سكة الحديد والطرق التى تهيئ التحرك للثاحنات من والى الأرصفة ، هذا إضافة الى محطة أرصد وتتبؤ جوية ، هذا بالاضافة الى كل العلامات

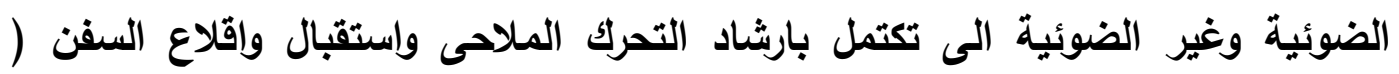

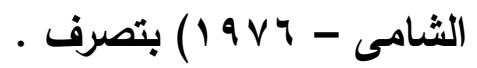

وعلى صعيد آخر تمتد سواحل محافظة جنوب سيناء الثرقية وإلغربية على خليجى السيويس والعقبة بطول يبلغ . . هكم تقريبا، وذلك الى الجنوب الشرقى لمحافظة السويس حتى رأس محمد فى أقصى الجنوب، ومن بئر طابه فى أقصى شمال خليج العقبة والذى يضم عددا من الموانئ والمرافئ والمراسى ، والتى تعتبر كثيرة بالمقارنة بالموانئ والمرافئ 
وإلمراسى المطلة على سواحل البحر المتوسط فى مصر.تأخذ سواحل محافظة جنوب سيناء الثرقية والغربية شكل حرف V v

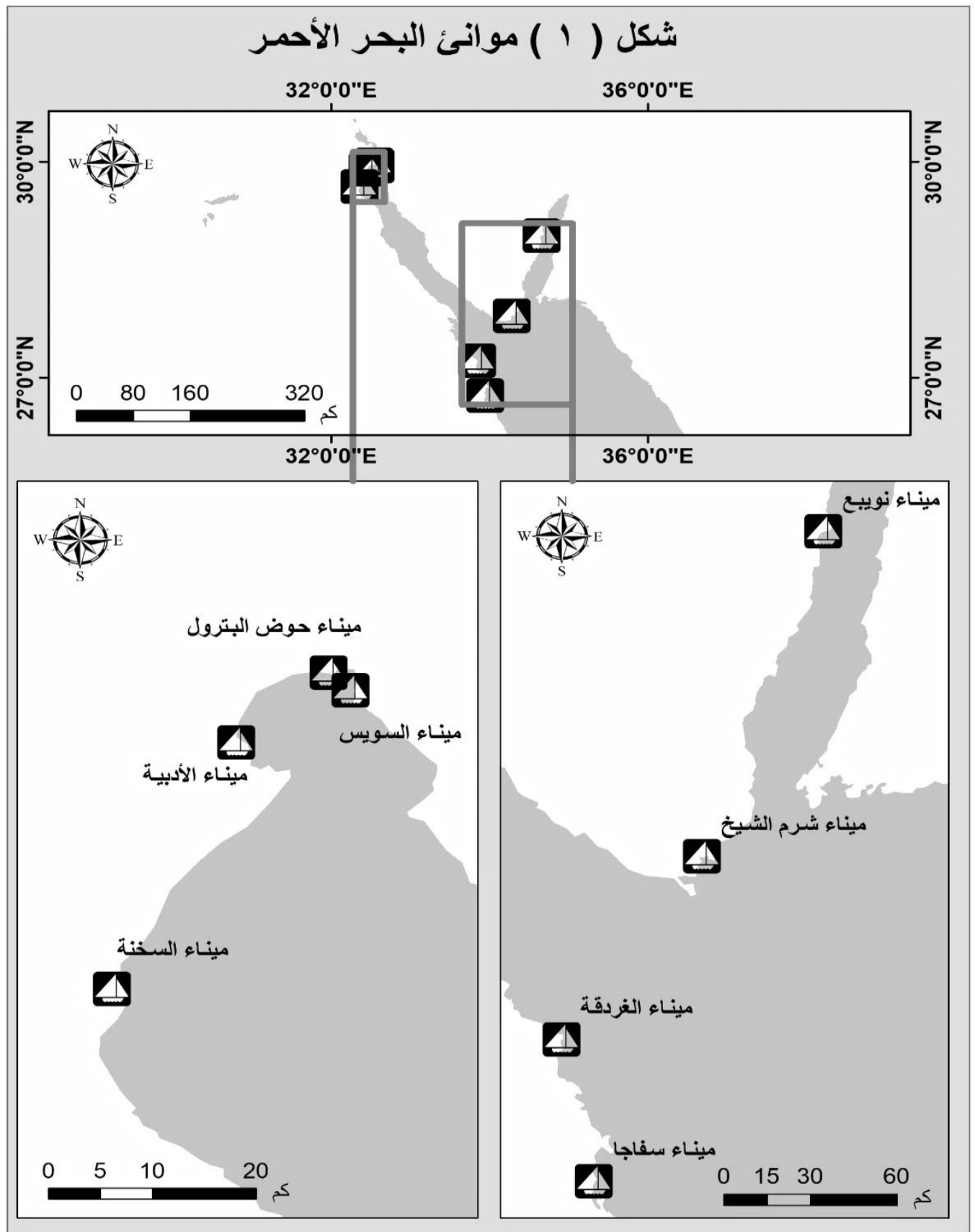

ويذا تنقسم إلى قسمين هما : الثرقي يطل على خليج العقبة ويمتد من طابه عند دائرة

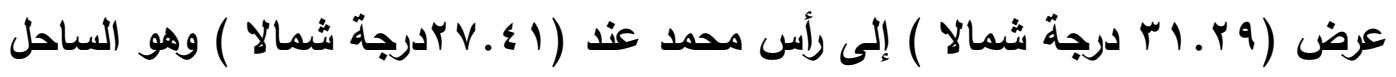




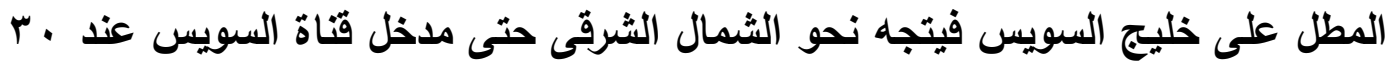
درجة شمالا ـ ويتسم الساحل الثرقي المطل على خليج العقبة بأن العمق أمامه كبير حيث تكثر بجنويه المراسي والثروم ، كما توجد أمامه عند مدخل الخليج جزيرتي تيران وصنافير مباشرة ، بحيث لا يوجد سهل ساحلى بالمغنى المفهوم حيث يتراوح أتساعه بين

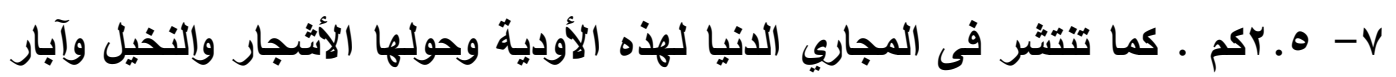
المياه الجوفية فيما يشبه الواحة ـ أما الساحل الغربي فهو متعرج وأكثر ضحالة فى في الثمال عنه فى الجنوب ، كما يندر أن تزيد الأعماق أمام الشاطئ عن ثلاث قامات ، ويمتد هذا العمق الضحل ناحية الثرق فى مناطق متعددة لأكثر من ميل بحرى ، أما الجزء الجنويى من هذا الساحل فى منطقة شراتيب وجنويها فإن هناتك أغوار على الثاطئ يزيد العمق بها عن عشرون قامة فى مناطق لا تبعد عن الساحل بأكثر من ريع ميل

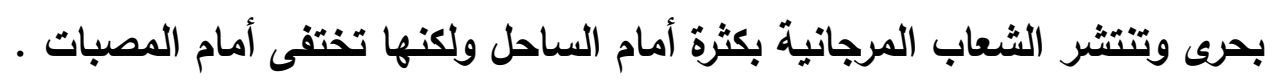
ويمكن ملاحظة الثعاب المرجانية فى شكل نطاق متصل بالقرب من الساحل فى المنطقة الممتدة من رأس مسلة حتى أبو زنيمة ، وكذلك حول ميناء الطور وهى تعرف بإسم أرجاج رياح . كما يمتد السهل الساحلى خلف خط الساحل وهو المطل على خليج السويس والذي يتباين فى اتساعه بين V- "rكم ويزيد عن ذلك قليلا فى بعض المناطق ، ولكنه فى الغالب أكثر إتساعا من نظيره المطل على خليج العقبة والذي يمثل بقعا تفصلها الحافات العالية والجروف الرأسية المطلة على الساحل مباشرة ـ ومن خلال دراسة مستويات

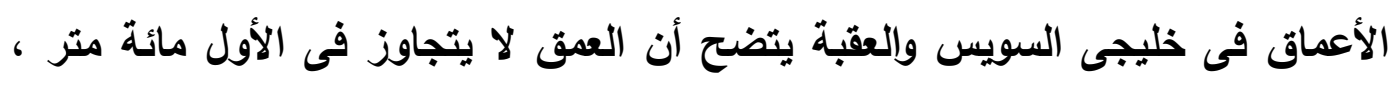
بينما تزيد بعضها فى الأخير على الألف متر ، ويؤكد هذا التباين إنحدار المرتفعات الثرقية رأسا على خط الساحل دون أن يكون هناك سهل ساحلى واضح ، بينما السهل الساحلى لخليج السويس محدد بوضوح ·

وقد ساهمت خصائص الجغراقية الطبيعية للسواحل التى تطل عليها محافظة جنوب سيناء فى توطن وتجهيز وتهيئة الموانئ والمرافئ ، هذا إضافة إلى خصائص النشاط الاقتصادى 
خاصة بالنسبة للمراسي والموانئ ذات الطابع المحلى والإقليمي (الثامى - 19 > بتصرف ) • ومن أهم الموانئ والمراسى التى تقع على خليجى السويس والعقبة الذان يثكلان الحدود الغربية والثرقية لمحافظة جنوب سيناء هى : مرسى رأس ملعب ، ميناء

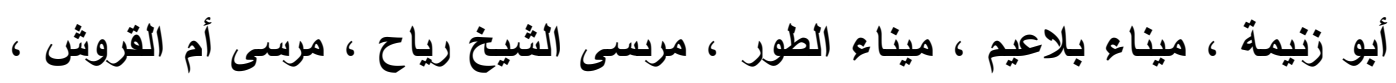

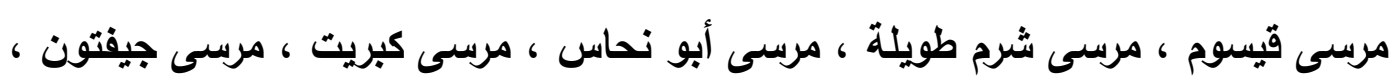

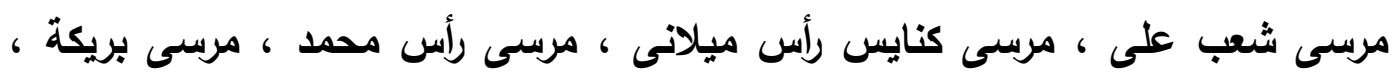

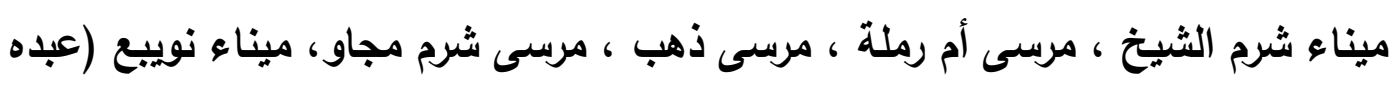

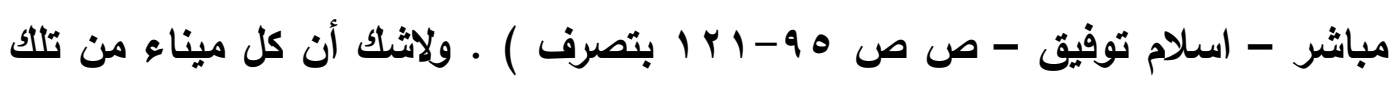
المذكورة سابقا يتسم بمجوعة من الخصائص والتجهيزات التى تجعل منهما يتميز عن الأخر ويرجع ذلك لخصائص الموقع والموضع وكنلك للاور الوظيفي الذى يتخصص فيه ، ويتضح ذلك من خلال العرض التالى :

- ميناء الطور : الأى يقع على الساحل الثرقى لخليج السويس وعند دائرة عرض I TV,O الجنوب من مدينة السويس ، وتبلغ المساحة الاجمالية للميناء

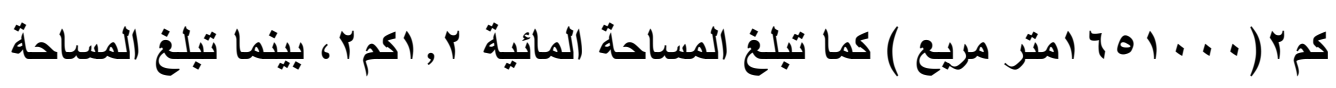

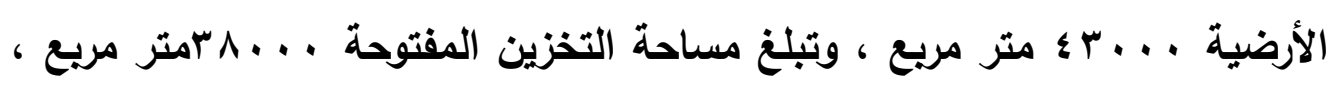

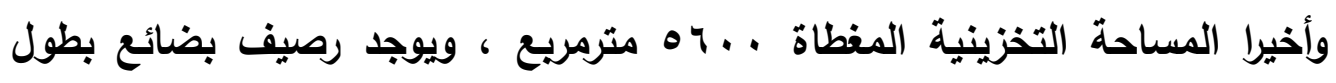

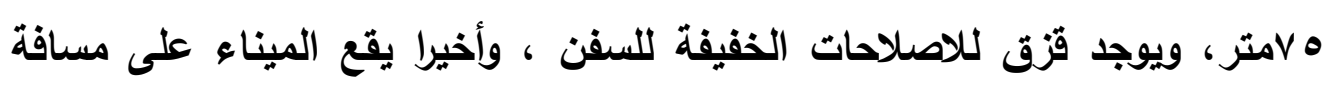

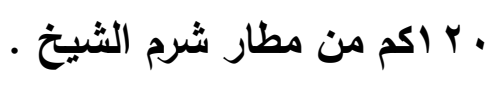
- ميناء شرم الثيخ : الذى يقع فى أقصى جنوب شبه جزيرة سيناء عند ملتقى خليجى

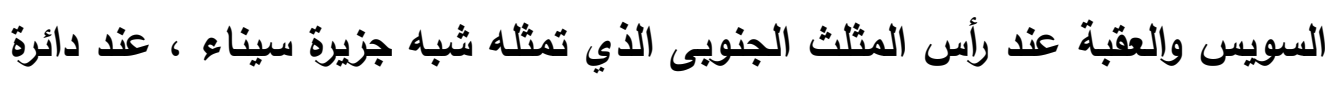
العرض 1V,O مدينة السويس ، وعلى مسافة ، 9 ؛كم من القاهرة ـ ويبلغ إجمالي مساحة الميناء 


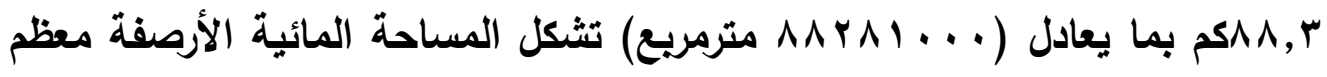

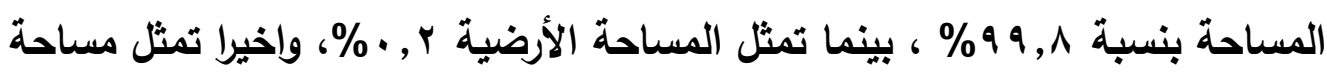
الساحات والمساحات امام رصيف اليخوت نسبة ضئيلة للغايةتتراوح بين ه ه.,..؟ . ., . \%،ويتوافربالميناء عدد هـ ـ 1 شمندورة لرياط ومبيت اليخوت السياحية سفن

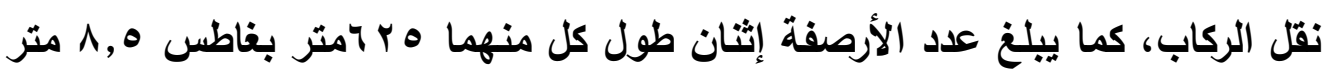
يعنى أنه أكثر عمقا من ميناء الطور، ويوجد قزق للاصلاحات الخفيفة وكذلك خدمات الامداد والتموين للسفن واليخوت سواء السولار أو المياه أو المواد العذائية ، وتصل الطاقة الاستيعابية القصوى للميناء . . ألف راكب سنويا بإعتبار أن الميناء يعمل لحساب نقل الركاب والحركة السياحية ، ويبتعد الميناء عن مطار شرم الثيخ بعشرة كيلومترات.

Y^,OV ميناء نويبع : الذي يقع على الساحل الغربى لخليج العقبة عند دائرة عرض -

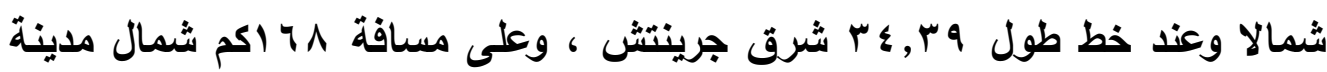
شرم الثيخ ومسافة § آكم جنوب طابا ، ويعتبر الميناء الأكبر من حيث المساحة فى لهى محافظة جنوب سيناء ، حيث تبلغ مساحته الاجمالية مايقرب من ·.كمر (^,^وكمץ)، تمثل المساحة المائية النسبة الكبرى ، كما كان الحال فى ميناء شرم

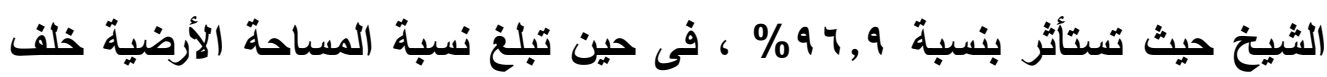

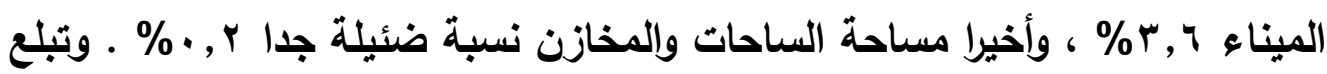

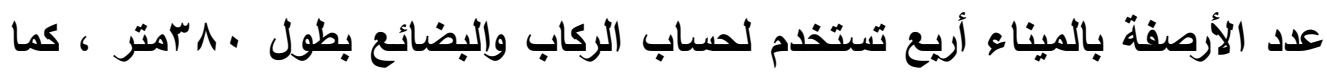
يبلغ أقصى غاطس للسفن ^ أمتار ، وتوجد بالميناء ورشة للإصلاحات الذفيفة للسفن كما هو الحال بالنسبة للموانئ السابقة .

ويذلك يعتبر ميناء نويبع هو الأفضل من حيث الأرصفة والغاطس المسموح به مما يجعله مناسبا لإستقبال ومغادرة السفن المتوسطة الحموئة التى تتعامل فى نقل الركاب والتى يتراوح عدد ركابها . . ـ- . . . راكب، وتعمل شركة الجسر العربي للملاحة بعدد من 
العبارات كخط منتظم بين مينائي نويبع والعقبة الأردني وقد تم تأسيهها سنة ه191ام كثركة مساهمة مصرية أردنية عراقية تساهم فى عملية الربط بين المغرب العربى

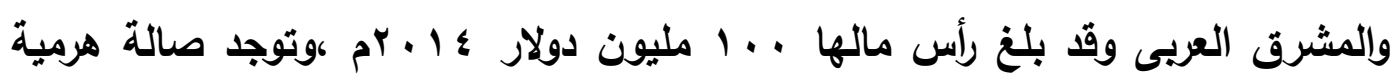

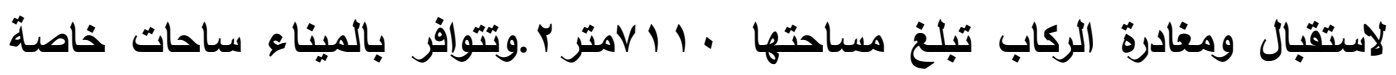
بشركة أوتوبيس شرق الدلتا وشركة السوير جيت الأردنية،وتبلغ الطاقة الاستيعابية القصوى للركاب مليون راكب سنويا ، إضافة إلى السيارات الخاصة وشاحنات الخضار والفاكهة (البرادات) حيث تبلغ الطاقة الإستيعابية القصوى للميناء • ه بألف طن سنويا ، وتتوافر بالميناء معدات شحن وتفريغ تتمثل فى عدد واحد ونش بطاقة عشرة أطنان وكلارك بطاقة خمس أطنان إضافة إلى عدد إثنان جرا رومانى ، ويعمل الميناء على مدار أريع وعشرون ساعة عكس مينائي الطور وشرم الثيخ اللذان يعملان خلال الفترة النهارية فى الغالب ، ويرتبط ميناء نويبع بباقى محافظات الجمهورية بشبكة طرق برية مرصوفة من خلال محاور رئيسة ثلاث هى :

- طريق نويبع - التمد - نخل - نفق الثهيد أحمد حمدى ، بطول ـ هاكم .

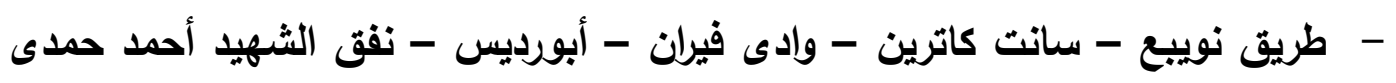

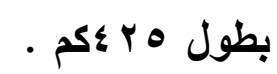

- طريق نويبع - شرم الثيخ - الطور - نفق الثهيد أحمد حمدى بطول . هوكم . أما فيما يتعلق بمعدل التباعد الاجمالى بين شبكة المراسى والمرافئ والموانئ على

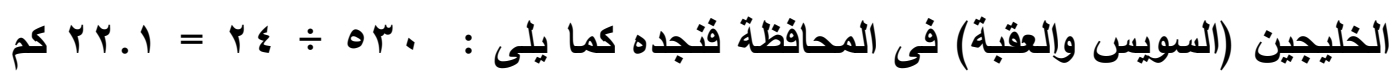
تقريبا ، بينما بلغ معدل التباعد على ساحل المحافظة الغربى المطل على خليج السويس له

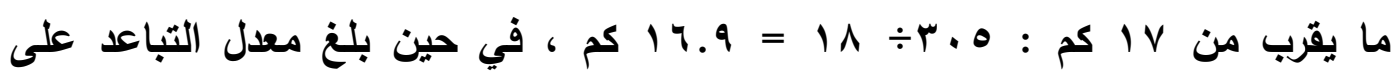
الساحل الثرقى للمحافظة المطل على خليج العقبة والمواجه للمملكة العربية السعودية مايقرب من VTSم : 
وعلى صعيد آخر يعتبر ميناء أبو زنيمة من الموانئ المتخصصة فى تصدير طينة الكاولين اللازمة لصناعة الصينى والبورسيلين حيث تنتشر تلك الخامات فى مناطق سبع سلامة وأبو نتش ووادى بدرة والتى تقع جميعها الى الثرق من ميناء أبو زنيمة ، وأيضا

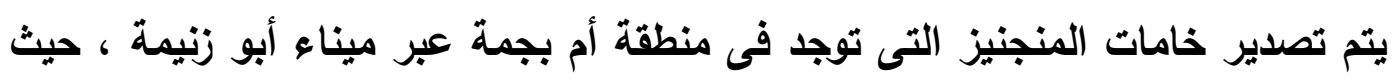
يبلغ الاستهلاك المحلى الخام المنجنيز فى الوقت الحاضر ، ولذلك فإن تعدين المنجنيز والمنجنيز الحديدى بشبه جزيرة سيناء يعتمد أساسا على التصدير ، حيث جرت العادة بتصدير خامات المنجنيز الى الدول المنتجه للحديد والصلب، ويتم تصدير المنجنيز فى لئ السنوات الماضية الى كل من الولايات المتحدة وهولاندا وألمانيا ويريطانيا وايطاليا ويلجيكا

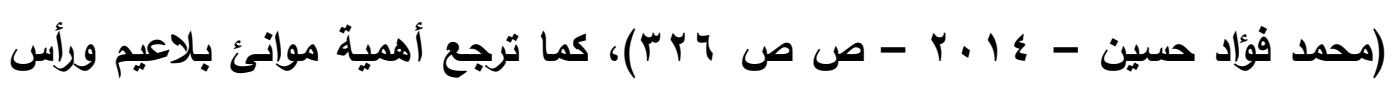

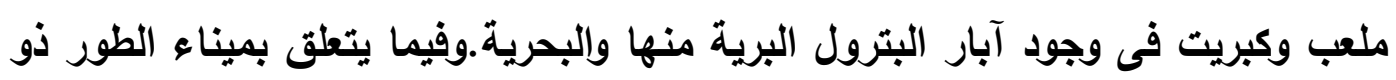
الأهمية التاريخية حيث كانت تتم إجراءات الحجر الصحى لحجاج البحر قبل دخولهم البلاد ، أما الوقت الحاضر فيستخدم لحساب عملية الصيد ، إضافة للأغراض العسكرية حيث

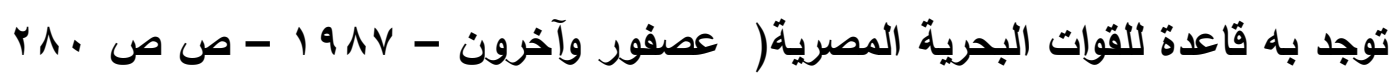
- 1 1 - بتصرف ) ـ أما بالنسبة لميناء شرم الثيخ والذى يرتبط بدرجة كبيرة بظهور

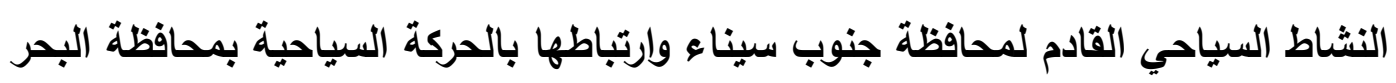
الأحمر عبر ميناء الغردقة على ساحل البحر الأحمر ، هذا اضافة إلى دوره كقاعدة للقوات

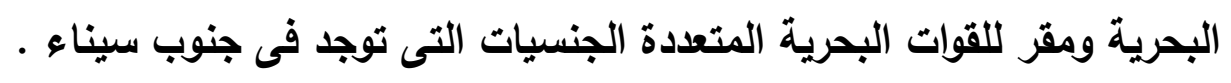

وأخيرا يأتى ميناء نويبع والذي يعتبر من أهم الموانئ فى محافظة جنوب سيناء وخاصة

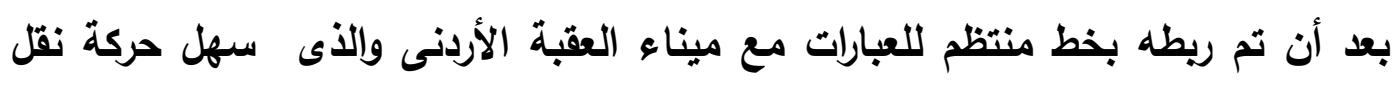
الركاب بين كل من مصر ودول الخليج العربية والأردن والعرلق ـ وأخيرا نجد أن لأحجام المحلات العمرانية وتوزيعها على سواحل جنوب سيناء وتوزيع حقول البترول وخامات

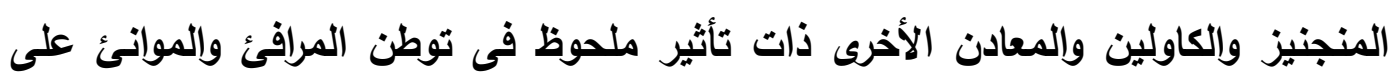
سواحل سيناء ، وذلك بشرط توافر ظروف الجغرافية الطبيعية من حيث ظهور النتواءات 
والرؤوس والثروم البحرية التى ساهمت بلرجة كبيرة أيضا فى توزيع تلك الموانئ والمرافئ التى تستخدمها قوارب الغوص لحساب العملية السياحة والتى توجد فى شرم

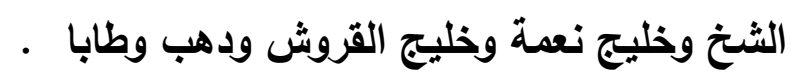

- حركة نقل الركاب والبضائع بموانئ جنوب سيناء :

تنقسم حركة نقل الركاب فى موانئ محافظة جنوب سيناء إلى نوعين : الأول يتمثل فى

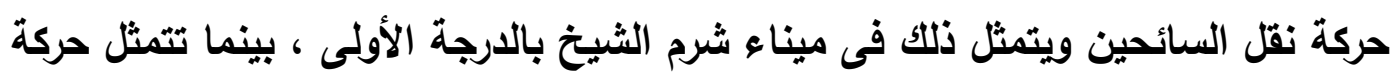
نقل الحجاج والمعتمرين ونسبة صغيرة من العمال بدول الخليج العربية والأردن عبر ميناء نويبع ، ويالطبع تأتى معظم الحركة النقلية من خارج المحافظة وذلك للصغر الثديد للحجم

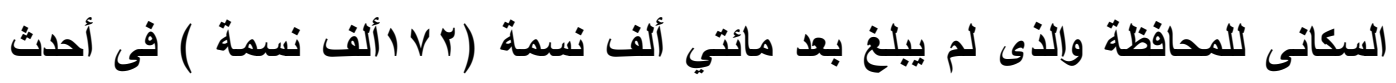
التقايرات مما يجعلها تثكل نسبة ضئيلة جدا من إجمالي سكان مصر، ويالتأكيد سينعكس ذلك على ضعف إستفادة السكان المحليين من خدمة النقل البحرى بإستثناء عملية صيد الأسماك المحدودة من بعض المرافئ.

ومن خلال تحليل حركة نقل الركاب والسائحين فى الموانئ المطلة على خليجى السويس

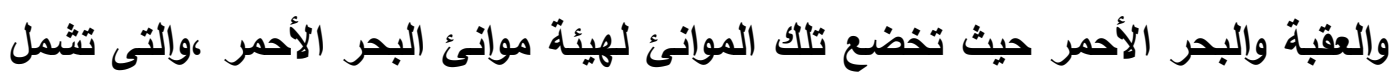
ست موانئ هى : ميناء السويس وميناء السخنة وميناء سفاجا وميناء نيويع وميناء الغردقة وميناء شرم الثيخ ، وقد بلغ إجمالى حجم الركاب والسائحين لتلك الموانئ خلال

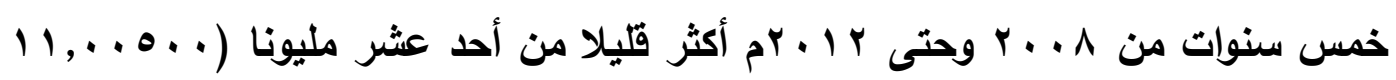
راكب) بمتوسط أكثر قليلا من مليوني راكب سنويا ( . . 1 ـ ب براكب ) ، وخلال السنوات

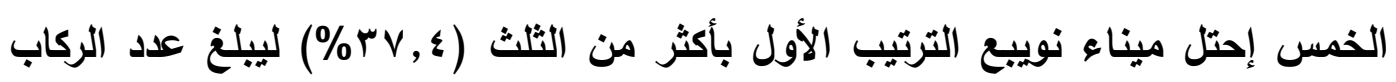

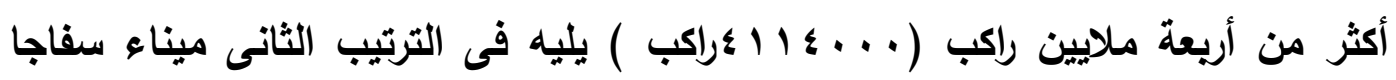

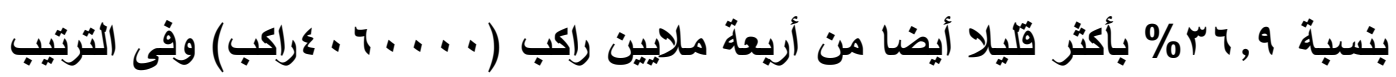
الثالث فقد جاء ميناء شرم الثيخ بأكثر قليلا من العثر (^, • 1\%) ليسجل أكثر قليلا من 
المليون راكب ( ... 19 (1 راكب) يليه فى الترتيب الرايع بفارق ضئيل ميناء الغردقة ليبلغ نسبة ه, • 1\% ويعدد ركاب يبلغ . . . 1109 راكب ، بينما تراجع مينائى السخنة

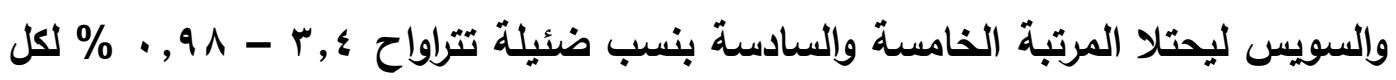
منها على التوالى ، ويرجع ذلك كونهما موانئ بضائع بالارجة الأولى . ومن ناحية أخرى تتابين حركة نقل الركاب من ميناء إلى آخر ومن سنة إلى أخرى، ففى سنة 1 . . r مبلغ إجمالى الركاب والسائحين للموانئ الست المذكورة أكثر قليلا من مليونين

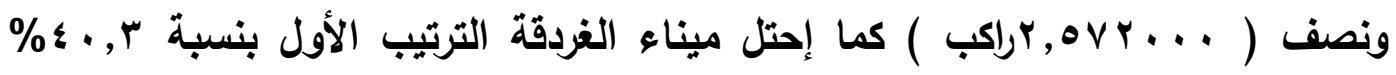
ويرجع ذلك لتثغيل العبارة السريعة على خط ضبا باللمملكة العربية السعودية وحتى ميناء الغردقة بمحافظة البحر الأحمر ويذلك يكون الراكب قد وفر مسافة (•ه اكم ) مقارنة بميناء سفاجا الذي يقع الى الجنوب وكنلك عزوف كثير من الركاب للتعامل مع ميناء سفاجا بعد حادث غرق العبارة السلام فى فبراير 7 . . ب ، يليه بفارق ضئيل فى الترتيب

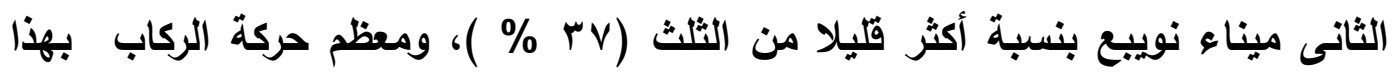
الميناء قادمة من شمال دول الظليج والأردن، ويبيما يأتى ميناء شرم الثيخ فى الترتيب الثالث بنسبة أكثر قليلا من العشر (ץ, ؛ ا \%) ،وهى تمثل أكثر قليلا من ريع حركة الركاب بميناء الغردقة، وهى فى معظمها حركة للسائحين القادمين من الغردقة أو المتجهين إليها

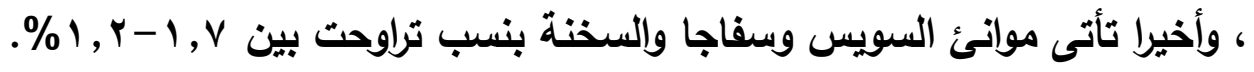

وعلى صعيد آخر فقد تناقص عدد الركاب للموانئ الست سنة r ب بrم بما يقرب من نصف مليون راكب ( . . 1 . ؛ راكب) حيث بلغ إجمالى الركاب فى تلك السنة أكثر قليلا

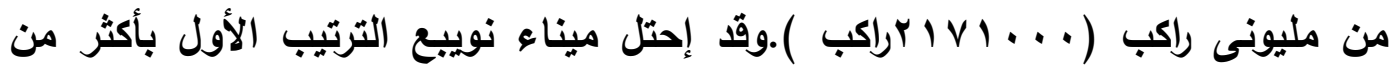
الثلث (1,1\%؟\%) بينما جاء ميناء الغردقة فى الترتيب الثانى بنسبة هץ\% ، بينما إحتل ميناء شرم الثيخ الترتيب الثالث بأقّل من عشر حركة الركاب (r,\% مسجلا تراجع كبير مقارنة بسنة ^ . . rم فى حين إرتفعت نسبيا مساهمة ميناء سفاجا والسخنة لتبلغ

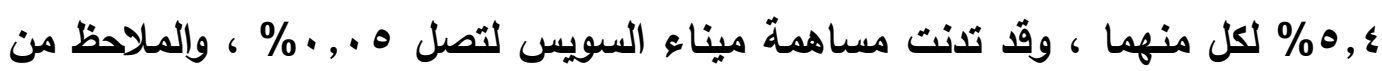




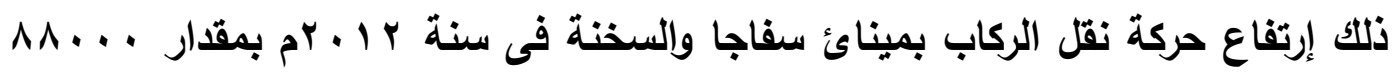
راكب لكل منهما مقارنة بسنة 1 . . بام ، وقد يرجع ذلك لتفضيل الركاب والحجاج القادمين والذاهبين لكل من المملكة العربية السعودية ودول الخليج المينائين الآخيرين بإعتبارهما أكثر أمانا بالمقارنة بموانئ جنوب سيناء وكذلك إنخفاض أعدد السائحين الأجانب القادمين لمحافظة جنوب سيناء بسب الظروف التى مرت بها مصر بعد ثورة يناير

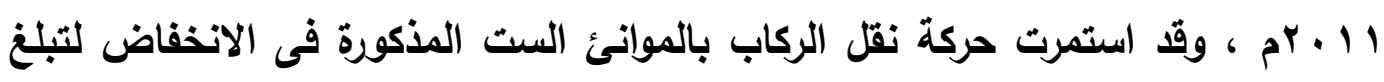

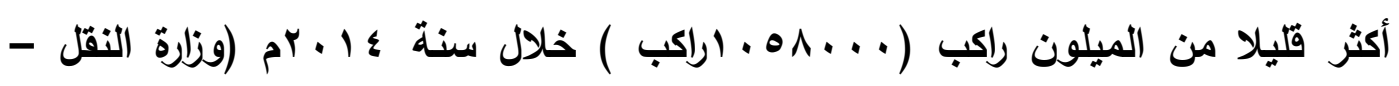
الهيئة العامة لموانئ البحر الأحمر - سنوات مختلفة ).

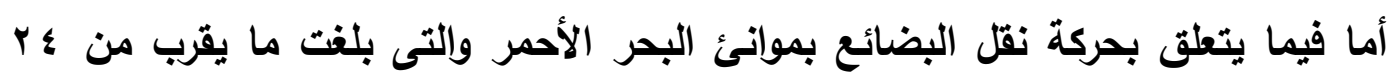

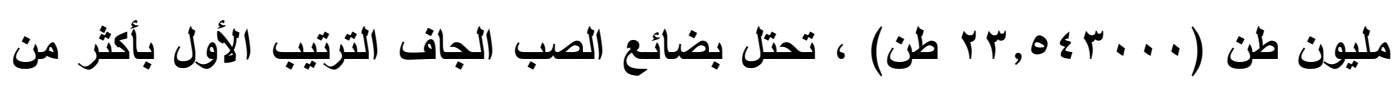

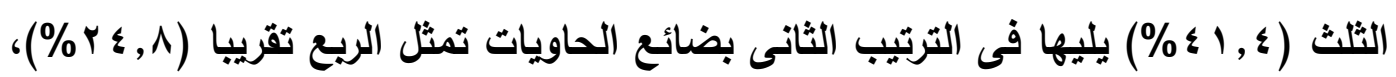

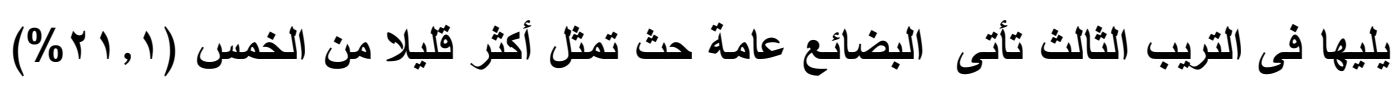

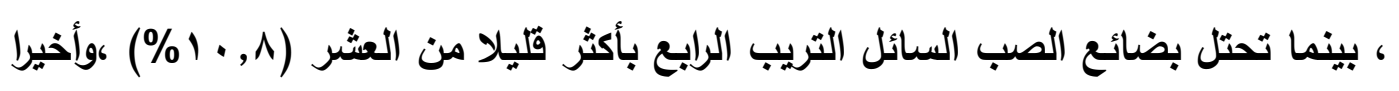

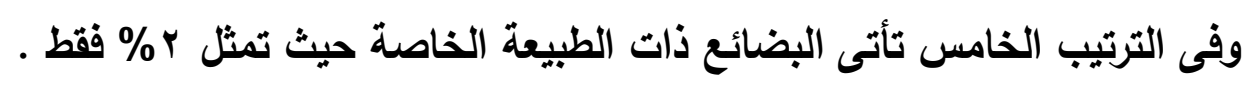
أما بالنسبة للتوزيع الجغرافي لحركة البضائع العامة المترددة على موانئ البحر الأحمر

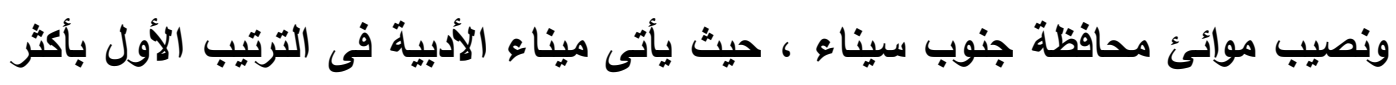
من النصف (1,vol\%) يليه فى الترتيب الثانى ميناء نويبع بنسبة أقل من الخمس

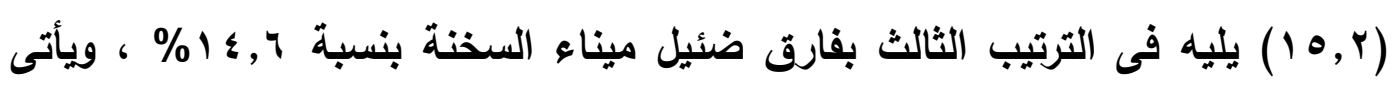

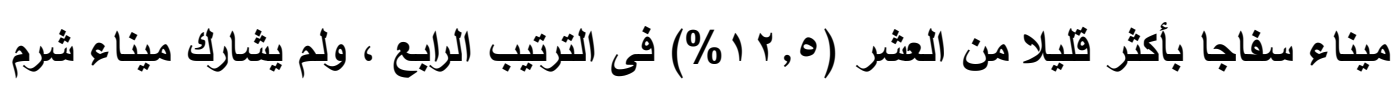
الثيخ فى حركة نقل البضائع العامة ، حيث يتخصص فى نقل الركاب لحساب النثاط

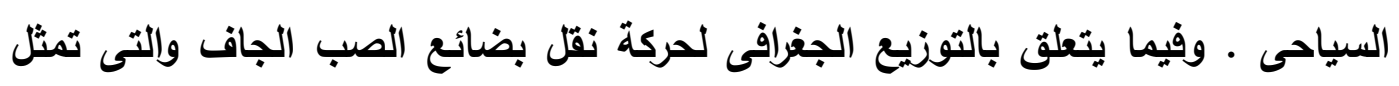

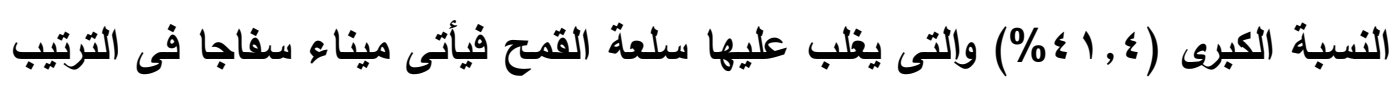
الأول بنسبة ؟, . ؛ \% ويتخصص فى نقل القمح الوارد من إستراليا الى محافظات الصعيد 
(محمد مرسى الحريرى - 1911- ص 9ه) يليه فى الترتيب الثاني ميناء الأدبية بأكثر

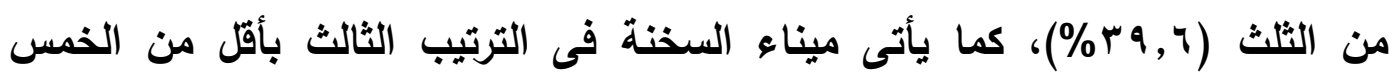

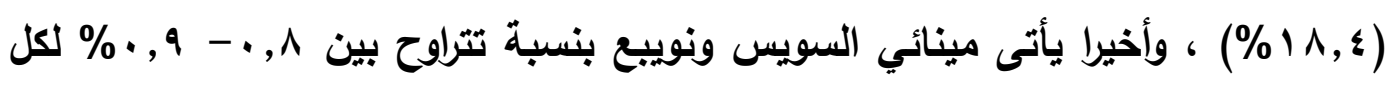

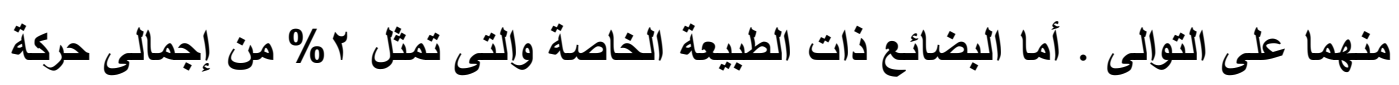

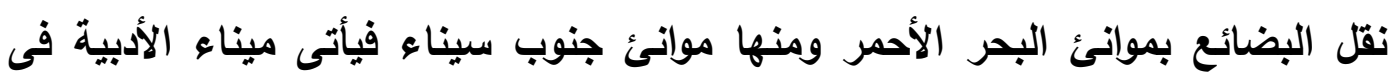
الترتيب الأول بمايقرب من التسعة أعثار (1/,1\%) ، يشاركه فى حركة النقليات لكن

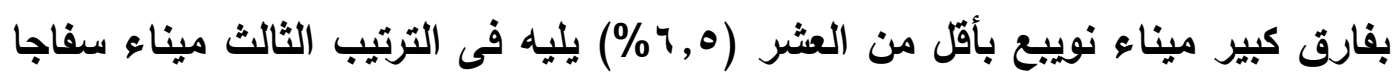

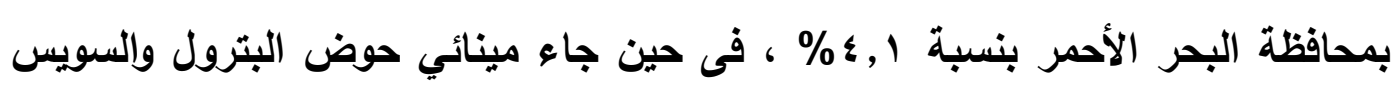

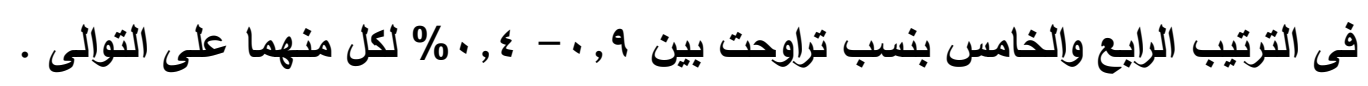
وفيما يتطق بيضائع الصب السائل والتى تمثل عثر (^, .1\%) حركة النقليات فيأتى ميناء حوض البترول فى الترتيب الأول بما يقرب من الثلثين (r, .ب٪\%) يليه ميناء الأدبية بأكثر قليلا من الثلث (؟,هr\%) وفى الترتيب الثالث بفارق كبير يأتى ميناء

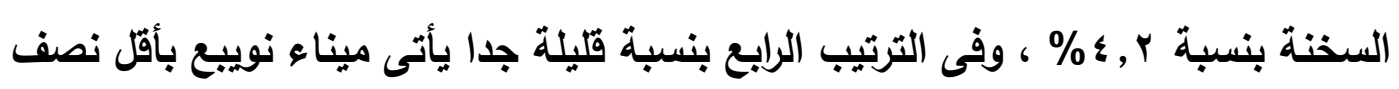

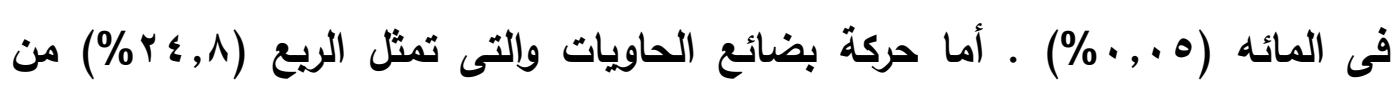
اجمالى كمية البضائع المنقولة فيستحوذ ميناء السخنة على الترتيب الأول بفارق كبير

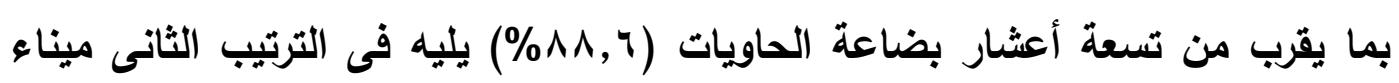
الأدبيه بأكثر قليلا من العشر (؟), 11\%) ، ولم تساهم باقى موانئ البحر الأحمر بما فيها

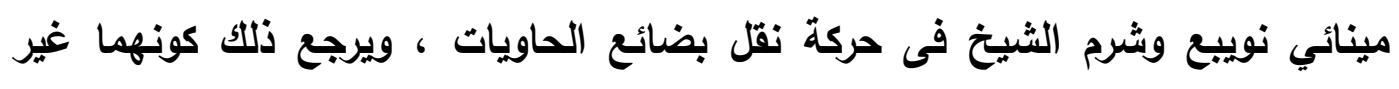

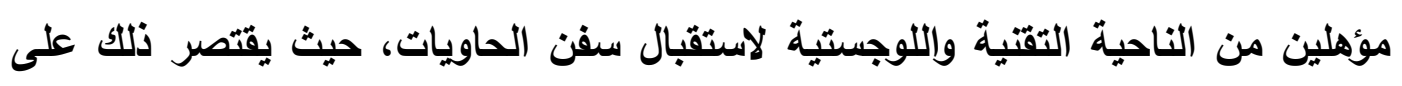
ميناء السخنة في شمال خليج السويس ويعض موانئ البحر المتوسط المصرية .

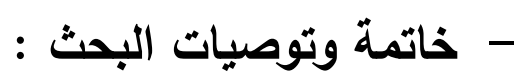


لقد تبين من خلال التحليل السابق لجغرافية الموانئ البحرية في جنوب سيناء بأنها يمكن أن تؤثر في عملية التنمية الاقتصادية والاجتماعية من خلال عدة محاور سوف

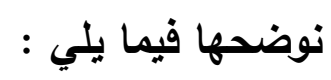

- تتمتع محافظة جنوب سيناء بسواحل طويلة تبلغ .. ككم حيث تطل على خليجي العقبة والسويس من الثرق والغرب والجنوب ، وذلك عكس كثير من المحافظات

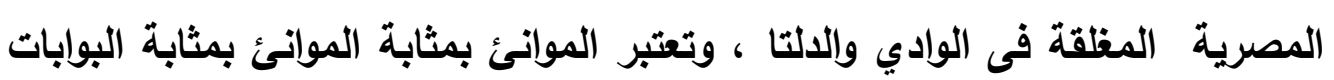
التي تطل من خلالها الدول والأقاليم على العالم الخارجي لحساب التبادل التجاري . - يتسم الظهير والبناء الاقتصادى لمحافظة جنوب سيناء بضعفه الكبير فى مجال الاقتصاد الزراعى وذلك بسبب قلة موارد المياه بالدرجة الأولى ، فى حين تتوافر مواد خام معدنية غير مستفلة بدرجة جيدة يمكن أن تسثمر الوفرة النسبية للمرافى والموانئ التى تطل عليها المحافظة. - يساهم النشاط السياحى بلرجة واضحة فى البناء الاقتصادى للمحافظة ويتضح ذلك من خلال عدد السائحين والمنثآت السياحية والليالى السياحية والايراد السنوى والذي لئي يستفيا من إمكانيات السواحل وإلمراسي والموانئ البحرية بمحافظة جنوب سيناء ، وخاصة فيما يتعلق بالتكامل السياحى بين المحافظة ومحافظة البحر الأحمر ويتضح

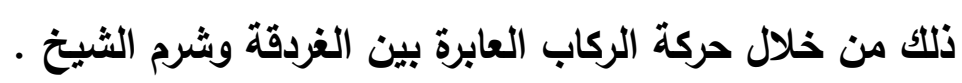
- تتباين موانئ جنوب سيناء من حيث المساحة والبنية والتجهيزات فهى متواضعة فى حنى

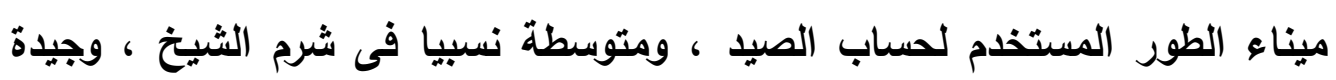
نسبيا فى ميناء نويبع ، ويجب تطوير تلك الموانئ كى تستجيب لعملية التنمية

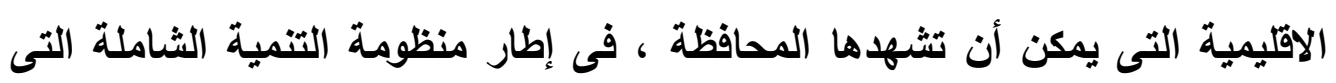

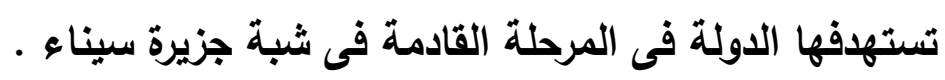
- يوجد بالمحافظة ثلاثة موانئ رئيسة هى: الطور وشرم الثيخ ونويبع ويمكن القول بالتخص الوظيفى لكل ميناء من تلك الموانى ، حيث صيد الأسماك فى ميناء الطور ، وحركة نقل الركاب السياحين فى ميناء شرم الثيخ ، وحركة نقل الركاب وكذلك 
الحجاج والمعتمرين بين مصر ودول الخليج العربى والأردن ، إضافة الى نقل الحجاج والمعتمرين فى ميناء نويبع ، والتى تثكل ضغطا على الميناء فى مواسم الحج والعمرة وعودة العمالة المصرية فى فصل الصيف . . - تراجعت حركة النقل البحرى سواء السياح أو الركاب العاديين خلال الفترة الأخيرة ، وقد يرجع ذلك نتيجة الظروف التى تمر بها سيناء ، والتى إنعكست سلبا على موانئ

$$
\text { جنوب سيناء. }
$$

- توصي الدراسة بضرورة رفع معدلات التنسيق والتكامل في الحركة النقلية بين موانئ جنوب سيناء وموانئ محافظة البحر الأحمر على الجانب الغربي للبحر الأحمر ، وذلك بهدف تعظيم العائد الاقتصادي والتنموي للموانئ المصرية الواقعة في حوض البحر الاحمر ككل والتعامل معها كوحدة واحدة في اطار تكاملي تخصصي ، وكذلك تجنبا لمنافسة غير مرغوب فيها يمكن أن تؤثثر سلبا على مستقبل التنمية في كل من المحافظتين - المبن - وتوصي الاراسة بضرورة الأخذ في الاعتبار مستقبل التنمية في موانئ جنوب سيناء بل موانئ محافظة البحر الأحمر عند انثاء الجسر البري الذي يريط بين المملكة العربية السعودية ومصر عند لسان رأس محمد في محافظة جنوب سيناء . - مراجع البحث :

- أحمد الزاملي - موانئ ساحل البحر الأحمر - ماجستير - جامعة القاهرة - 191. - صلاح الدين على الثامي - النقل ، دراسة جغرافية - منشأة المعارف - الاسكندرية - pl9v4 -

- عبده مباشر - اسلام توفيق - سيناء الموقع والتاريخ - دار المعارف - القاهرة . - محمود عبد اللطيف عصفور وأخرون - جغرافية النقل في مصر - مكتبة النهضة . plaAv

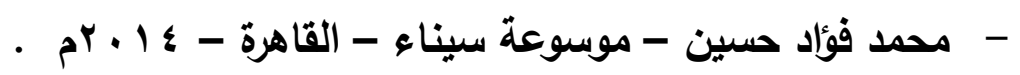

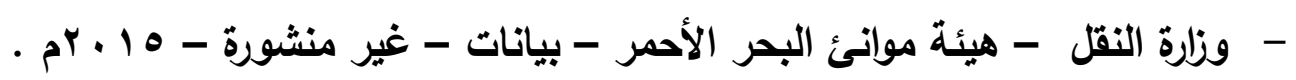




\section{- مراجع غير عربية :}

1. Adolf, $\mathrm{N}$ - and - Ducruet , $\mathrm{C}$-The changing tides of port geography (19502012)-Progress in Human Geography -38-2014.

2. Brandenburger,A-and- Nalebuff,B-Co-opetition, A Currency Book - New York -1996.

3. Evangellsta,P-Morvillo,A-2000-Logistical Integration and Co-Operative Strategies in Liner Shipping Some Empirical evidence, International Journal Of Maritime Economic, 2-1-16.

4. Gouvernal ,E-Daydou , J - Container Rail Fright Services in North - West Europe : Diversity of Organizational Forms in Liberalizing Environment, Transport Review , 25-557-571.

5. Hall,P-Container Ports, local benefits and transportation worker earningsGeoJournal-74-2009.

6. Heaver,T,2002-The Evolving Roles of Shipping Lines in International Legists, International Journal of Maritime Economics , 4-210-230.

7. Hoyle,B-The port city interface : Trends, problems and examples Geoforum - 20- 1989 .

8. Mangan, C,et- al - Port centric logistics - International Journal Logiest Management -19-2008.

9. McCalla,R-Golabl change, local pain : intermodal seaport terminals and their serves areas - Journal of Transport Geography -7-1999.

10. Monios, J- Integration intermodal transport with logistics : a case study of the UK retail sector - Transport Planning Technology - 35-2015 .

11. Notteboom,T-Traffic Inequality in Seaport Systems Revisited -Journal of Transport Geography - 14-2006. 